\title{
THE EFFECT OF THE BIOFUEL PROPERTIES ON THE AUTOIGNITION DELAY IN A DIESE ENGINE
}

\author{
Marius Mažeika ${ }^{1}$, Gvidonas Labeckas ${ }^{2}$, Oleg Klyus ${ }^{3}$, Irena Kanapkiené ${ }^{1}$ \\ ${ }^{1}$ Kaunas University of Applied Engineering Sciences, ${ }^{2}$ Aleksandras Stulginskis \\ University, ${ }^{3}$ Maritime University of Szczecin \\ E-mail: ${ }^{1}$ marius.mazeika@yahoo.com, ${ }^{2}$ gvidonas.labeckas@asu.lt, \\ 3olegklus@o2.pl, ${ }^{2}$ kanapkiene.irena@gmail.com
}

Received 2014-06-12, accepted 2014-09-14

The article presents the test results of a four-stroke, four-cylinder, naturally aspirated, DI $60 \mathrm{~kW}$ diesel engine operating on diesel fuel (DF) and its 5 vol\% (E5), 10 vol\% (E10), and 15 vol\% (E15) blends with anhydrous (99.8\%) ethanol (E). An additional ethanol-diesel-biodiesel blend E15B was prepared by adding the $15 \mathrm{vol} \%$ of ethanol and 5 vol\% of biodiesel (B) to diesel fuel ( $80 \mathrm{vol} \%)$. The purpose of the research was to examine the influence of the ethanol and RME addition to diesel fuel on the start of injection and autoignition delay. The widely differing physical and chemical properties of the biofuel blends along with engine load and speed modes were taken into account to provide sound analysis of the experimental test results.

Studies showed that the density of biofuel blends E5, E10, E15 and E15B was $0.33 \%, 0.65 \%, 0.95 \%$ and $0.56 \%$ lower at the temperature of $40{ }^{\circ} \mathrm{C}$ than the corresponding value $\left(0.828 \mathrm{~kg} / \mathrm{m}^{3}\right)$ of diesel fuel. Kinematic viscosity of biofuel blends E5, E10, E15 and E15B also decreased by $7.8 \%, 11.0 \%, 13.0 \%$ and $10.8 \%$ at the temperature of $40{ }^{\circ} \mathrm{C}$ and the cetane number was 3\%, 9\%, $14 \%$ and $12 \%$ lower, respectively, compared to commercial diesel fuel. The use of biofuel blends E15 and E15B the autoignition delay increased by $4.4 \%$ and $9.5 \%$ compared to normal diesel operation at full $\mathrm{p}_{\mathrm{e}}=0.67 \mathrm{MPa}$ (100\%) load and $1400 \mathrm{rpm}$ speed at which maximum torque occurs.

\section{Introduction}

The internal combustion engine (ICE) is one of the main users of fossilorigin liquid fuels. The production of petroleum fuel required for internal combustion engines reaches about 3.5 billion tons and this capacity is under steady rise. Meanwhile, the global petroleum reserves constitute approximately 140 billion tons as determined by calculations made by the scientists. Thus, at the assumption that petroleum needs will remain at the same level and the oil extraction capacities will not increase in the future, the petroleum resources would be sufficient merely for several decades (Labeckas et al., 2008; Garipov et al., 2008). Also, no alternative, which the internal combustion engines could replace by other type of mechanical energy generators, is estimated for the nearest future. The declining resources of fossil origin petroleum fuel and natural gas along with 
negative effects of the exhaust emissions of internal combustion engines on the ecological situation are the global problem of contemporary global energetics.

The total power output of ICE compiles around $80 \%$ of the power of all machines used in global energetics. The internal combustion engine, as a main generator of mechanical energy, has no suitable alternative in the field of road, water, and railway transport as well as in agriculture, horticulture, construction engineering sectors, and other fields were engines are used. Currently, there are more than 700 million vehicles operating on petroleum products on a global market. As many as 60 million automobile engines are entirely manufactured per year. The manufacture of stationary ICE also exceeds 10 million per year (Labeckas, 2008).

The EU Directive 2009/28/EC approved a target of a $20 \%$ share of renewable biofuels in overall transport petrol and diesel consumption by 2020 to be introduced in a cost-effective way. The principal reasons for using of biofuels are to lower greenhouse gas emissions, increase farm income, promote rural development and diversification, create a new dynamics in a global agricultural market, increase energy independence and reduce consumer reliance on imported fossil fuels (Labeckas et al., 2014).

\section{Purpose of the research}

To analyse the effect of bioethanol and RME addition to diesel fuel on physical and chemical properties of biofuel blends and, as a results, on the start of injection and autoignition delay when running at various loads and wide range of speed, including $1400 \mathrm{rpm}$ at which maximum torque occurs and rated $2200 \mathrm{rpm}$ speed.

\section{Methods of Experimental Research}

The stand tests were performed with the direct injection (DI) diesel engine D-243 mounted at the Engine Test Laboratory of the Institute of Power and Transport Machinery Engineering of the Engineering Faculty of Aleksandras Stulginskis University (ASU). The engine parameters related to the fuel energy conversion efficiency and exhaust emission parameters were measured according to the ISO 3046-1:2002, ISO 3046-2:1987 and ISO 3046-3:2006 standards.

The schematic layout of the engine test stand and measurement equipment are presented in Fig. 1. The tested engine was properly attached and the drive shaft was connected to the loading stand. The air was supplied to the engine via the AVL air flow meter. The fuel from the tank was delivered to the fuel injection pump via the AVL fuel-mass flow meter. The exhaust gasses were removed via the central collector to the atmosphere. The temperature of the exhausts was measured with a thermocouple

The density and kinematic viscosity of biofuel blends E5, E10, E15, and E15B along with diesel fuel used for experiments were tested at the Environmental Technology Chemical and Biochemical Research Laboratory, Institute of Environment of Aleksandras Stulginskis University. Density and kinematic viscosity of the tested fuels was measured by using a device Anton Paar SVM 3000 
manufactured in Austria. This devise provided the measurement accuracy of parameters about $0.0002 \mathrm{~g} / \mathrm{cm}^{3}$ and $\pm 0.1 \%$, respectively.

In experimental studies, the cetane number of biofuel blends was investigated at the laboratory of Quality Research Center of light petroleum products at the refinery "ORLEN Lietuva", Lithuania. The cetane number for the normal diesel fuel, which was used as a "baseline" parameter, and for biofuel blends E5-E15B was determined by using device "CFR WAUKESHA with the measuring accuracy of $\pm 0.1 \%$.

\section{Preparation of Fuel Blends}

The following three types of fuel were used to prepare biofuel blends:

- Diesel fuel, class 2 (CS51), corresponding to the requirements of LST EN 590:2009+A1 (ORLEN Lietuva Ltd).

- Water proof (200\%) bioethanol corresponding to the requirements of LST EN 15376:2008 ("Biofuture" Ltd).

- Rapeseed oil methyl ester (RME) corresponding to the requirements of LST EN 14214:2009 ("Rapsoila" Ltd).

Normal diesel fuel and 4 different biofuel blends E5, E10, E15 and E15B, were used for the experiments.

Table 1. Fuels and biofuel blends used in the tests

\begin{tabular}{|l|c|c|c|}
\hline & Diesel fuel, vol\% & Ethanol, vol\% & RME, vol\% \\
\hline D & 100 & 0 & 0 \\
\hline E5 & 95 & 5 & 0 \\
\hline E10 & 90 & 10 & 0 \\
\hline E15 & 85 & 15 & 0 \\
\hline E15B & 80 & 15 & 5 \\
\hline
\end{tabular}

\section{Determination of physical properties of fuels and fuel blends}

The following physical properties of fuels and their blends were analysed:

1. Density according to LST EN ISO 12185:1999. Crude petroleum and petroleum products. Determination of density. Oscillating U-tube method.

2. Kinematic viscosity according to LST EN ISO 3104+AC:2000. Petroleum products. Transparent and opaque liquids. Determination of kinematic viscosity and calculation of dynamic viscosity.

3. Cetane number according to LST EN ISO 5165:1999. Petroleum products. Determination of the ignition quality of diesel fuels. Cetane engine method (ISO 5165:1998). 


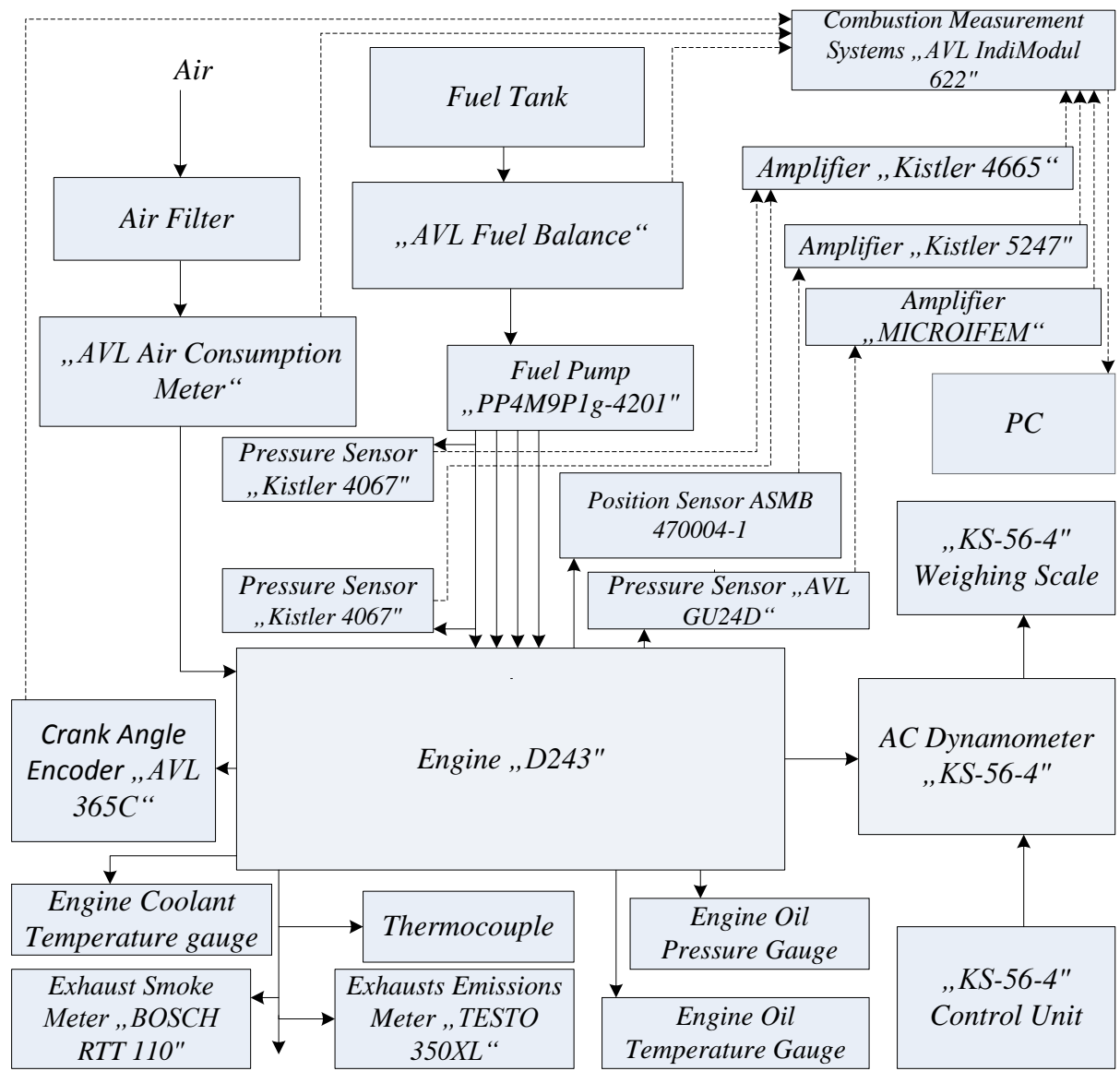

Fig. 1. Schematic layout of the engine test stand

Table 2. Engine specifications

\begin{tabular}{|l|l|}
\hline Engine producer & MTZ, Minsk (Belarus) \\
\hline Engine model & In-line, 4 stroke, 4 cylinder, water-cooled \\
\hline Cylinder bore $x$ piston stroke & $110 \mathrm{~mm}$ x $125 \mathrm{~mm}$ \\
\hline Splash volume & $4.75 \mathrm{dm}^{3}$ \\
\hline Compression ratio & $16.0: 1$ \\
\hline Combustion chamber & Toroidal in a piston head, direct injection $(\mathrm{DI})$ \\
\hline Rated power output & $60 \mathrm{~kW}$ at $2200 \mathrm{rpm}(\mathrm{bmep}=0.689 \mathrm{MPa})$ \\
\hline Injection pump & In-line, PP4M9P1g-4201 $(\mathrm{Czech}$ Republic) \\
\hline Plunger diameter x stroke & $9.0 \mathrm{~mm}$ x $8.5 \mathrm{~mm}$ \\
\hline Injector's type & DOP122S532-4164 MP 5 x 0.34 \\
\hline Needle-valve lifting pressure & $19.0 \pm 0.5 \mathrm{MPa}$ \\
\hline Needle diameter x mass & $5.0 \mathrm{~mm}$ x $7.0 \mathrm{~g}$ \\
\hline Static fuel injection timing & $25 \mathrm{CAD}$ before top dead center (BTDC) \\
\hline
\end{tabular}




\section{The influence of bioethanol and RME addition to diesel fuel on physical and chemical properties of biofuel blends}

Elemental Composition. When ethanol is poured into diesel fuel, the elemental composition of the biofuel blend is changed. The $\mathrm{C}: \mathrm{H}: \mathrm{O}$ ratio of the fuel blend was calculated according to the addition principle:

$$
\phi_{d}(C+H+O)_{d}+\phi_{e}(C+H+O)_{e}+\phi_{r m e}(C+H+O)_{r m e}=1,
$$

where: $\phi_{d}$ - diesel fuel (mass) part in the blend;

$\phi_{e}-$ ethanol (mass) part in the blend;

$\phi_{r m e}-\mathrm{RME}$ (mass) part in the blend;

$\mathrm{C}+\mathrm{H}+\mathrm{O}-$ the elemental composition of the respective substances.

Table 3. Compositions of the ethanol, diesel fuel, RME and corresponding blends

\begin{tabular}{|c|c|c|c|c|c|c|c|}
\hline $\begin{array}{c}\text { Element (mass) } \\
\text { parts }\end{array}$ & $\begin{array}{c}\text { Diesel } \\
\text { fuel }\end{array}$ & Ethanol & RME & E5 & E10 & E15 & E15B \\
\hline$g_{C}$ & 0.870 & 0.522 & 0.770 & 0.853 & 0.835 & 0.818 & 0.813 \\
\hline$g_{H}$ & 0.126 & 0.130 & 0.121 & 0.127 & 0.126 & 0.127 & 0.126 \\
\hline$g_{O}$ & 0.004 & 0.348 & 0.109 & 0.021 & 0.038 & 0.056 & 0.061 \\
\hline
\end{tabular}

\section{The test results and analysis}

The analysis of scientific studies, conducted on diesel engine running on biofuel blends, shows that the fuel efficiency and exhaust emissions largely depend on the density of biofuel blends, viscosity, calorific value and other parameters (Shahir et al., 2014). The fuel density is one of the most important fuel properties, which affects the development of the fuel spray in the engine cylinder and fuel atomisation characteristics. Since the cyclic fuel delivery is measured by volume, the lower is density of the fuel, the less fuel mass is injected into the engine cylinder per cycle that actually affects the air and fuel ratio of combustible mixture prepared. The lower density and higher compressibility of the bioethanol may delay the actual start of injection with regard to TDC. To the later start of injection may contribute also the higher internal leakages in the plunger-barrel and needle-valve-body units due to lover density of ethanol. The density of ethanol fuel $\left(0.791 \mathrm{~g} / \mathrm{cm}^{3}\right)$ is $4.7 \%$ lower than that of diesel fuel $0.828 \mathrm{~g} / \mathrm{cm}^{3}$ (both at the temperature of $20^{\circ} \mathrm{C}$ ), therefore the density of ethanoldiesel fuel blends (Fig. 2) is lower compared with that of normal diesel fuel. Similar results were obtained by researchers Çetin et al., 2009, Weber de Menezes et al., 2006; Barabas et al., 2010. 


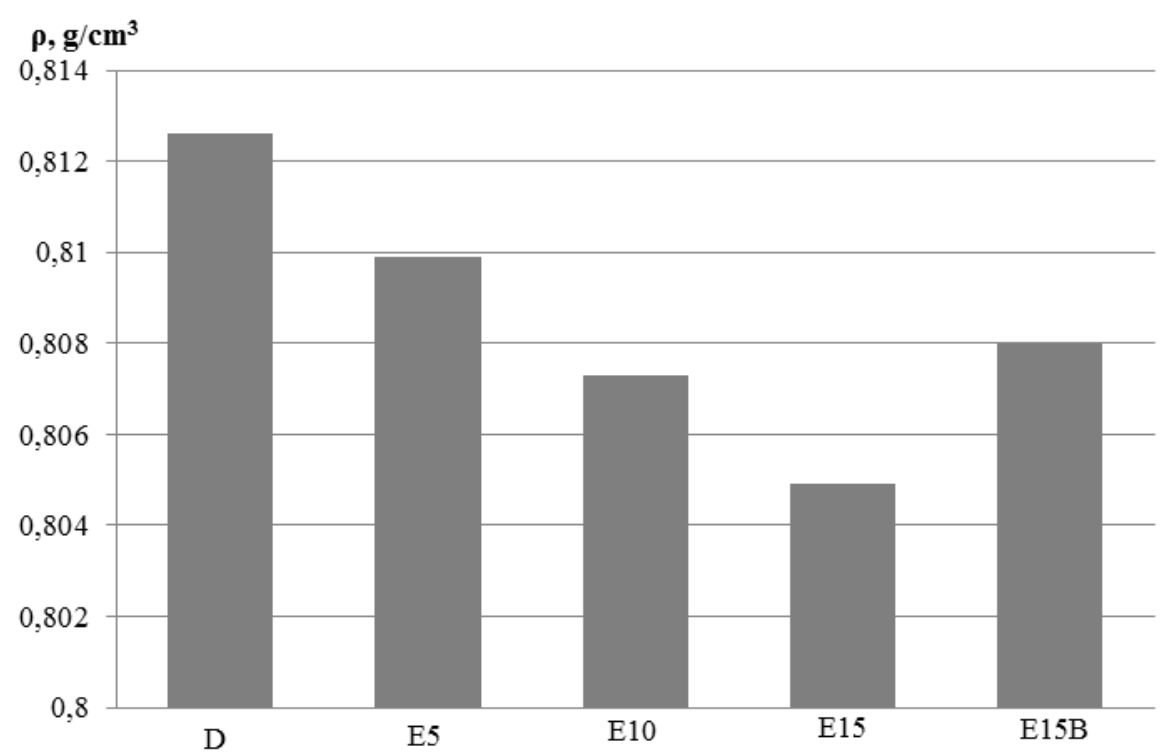

Fig. 2. The density of diesel fuel (D) and its blends with ethanol (E5, E10, E15) and $\mathrm{RME}(\mathrm{E} 15 \mathrm{~B})$ at the temperature of $40{ }^{\circ} \mathrm{C}$

The alcohol and diesel fuel blends have lower viscosity (Weber de Menezes et al., 2006). The lower viscosity of ethanol and diesel fuel blends may reduce the fuel spray penetration in the combustion chamber volume and increases the initial spray cone angle. The lower density typically results in a smaller Sauter mean droplet diameter, thereby increasing the total surface area of the fuel droplets distributed across the combustion chamber volume and thus substantially influences evaporation characteristics of the fuel (Shahir et al., 2014). The latter improves the air and bioethanol vapours mixing, i.e. improves homogeneity of combustible mixture, and thus reduces the maximum temperature in the combustion chamber. This, in turn, may have a positive effect on reduction of $\mathrm{NO}_{\mathrm{x}}$ emissions, which mainly depend on the maximum temperature in fuel-rich areas of the cylinder (Rakopoulos et al., 2007).

The kinematic viscosity of ethanol is $1.10 \mathrm{~mm}^{2} / \mathrm{s}$ (Weber de Menezes et al., 2006), which is significantly lower than the viscosity of conventional diesel fuel $\left(2.21 \mathrm{~mm}^{2} / \mathrm{s}\right)$. In our case, the viscosity of RME was $4.79 \mathrm{~mm}^{2} / \mathrm{s}$, - so the higher viscosity of biodiesel slightly increased the viscosity of three-component fuel blend E15B compared with that of ethanol-diesel fuel blends. The kinematic viscosity of biofuel blends used in experiments is shown in Fig. 3. Kinematic viscosity of blends E5, E10, E15 and E15B was 7.8\%, 11.0\%, 13.0\% and 10.8\% lower, respectively, than that of diesel fuel at the temperature of $40{ }^{\circ} \mathrm{C}$. Although the viscosity of ethanol and diesel fuel blends was lower than commercial diesel fuel, 
nevertheless it corresponded to the standard requirements for diesel fuel (from $1.50 \mathrm{~mm}^{2} / \mathrm{s}$ to $4.00 \mathrm{~mm}^{2} / \mathrm{s}$ ).

The test results related to changes of kinematic viscosity obtained mixing fossil diesel fuel with bioethanol are similar to those presented by other researchers (Torres-Jimenez et al., 2011, Lapuerta et al., 2010).

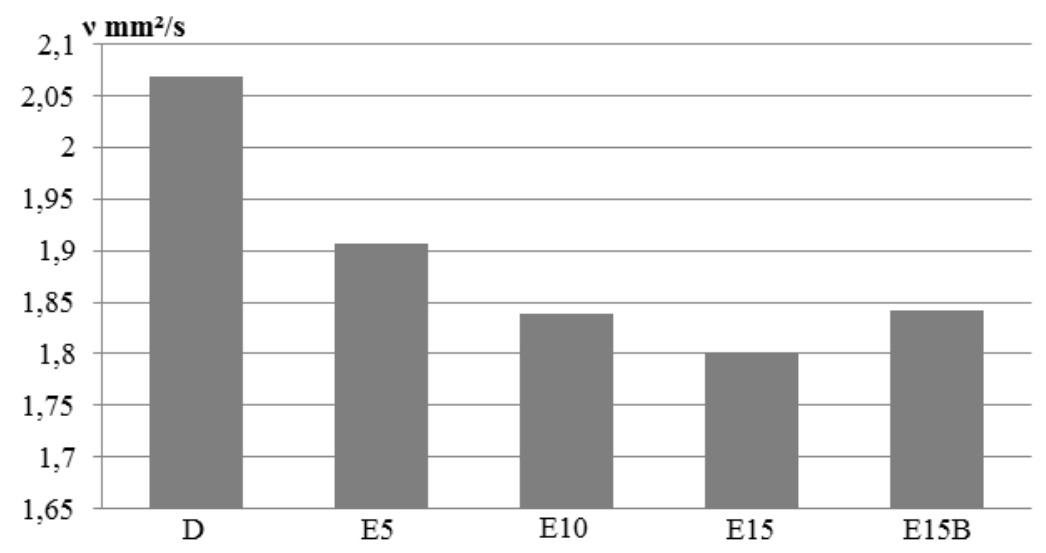

Fig. 3. Kinematic viscosity of diesel fuel (D) and its blends with ethanol (E5, E10, E15) and ethanol-RME fuels (E15B) at the temperature of $40^{\circ} \mathrm{C}$

Using of biofuels (ethanol) with too low viscosity may provoke a greater wear of the surface of precision plunger-barrel and the needle-valve-bodies (Pukalskas, 2002). The wear of sensitive the fuel pump and injectors' units can be reduced by the addition of proper amount of RME to ethanol-diesel fuel blends.

One of the most important parameters of a diesel fuel is the cetane number $(\mathrm{CN})$. The cetane rating is a very important factor of biofuel blends, especially in case of using diesel fuel mixtures with $34.8 \mathrm{vol} \%$ of oxygen-containing ethanol. As the analysis of literature shows (Matijošius 2011), the additive principle used for calculation of the cetane number of the fuel blend may not always lead to having the correct $\mathrm{CN}$ result.

The cetane number of the tested biofuel blends was determined experimentally in accordance with standard BS EN ISO 5165: 1999 and calculated by using additives method.

Analysis of experimental data of the cetane number shows (Fig. 4) that biofuel blends E5, E10, E15 and E15B differed as having CN ratings 3\%, 9\%, 14\% and $12 \%$ lower, respectively, compared with that of diesel fuel (51.5).

The test results obtained by other researchers ( $\mathrm{Li}$ et al., 2005; Weber de Menezes et al., 2006) show that the cetane number of biofuel blends exhibits similar changing trends as in the present case. 


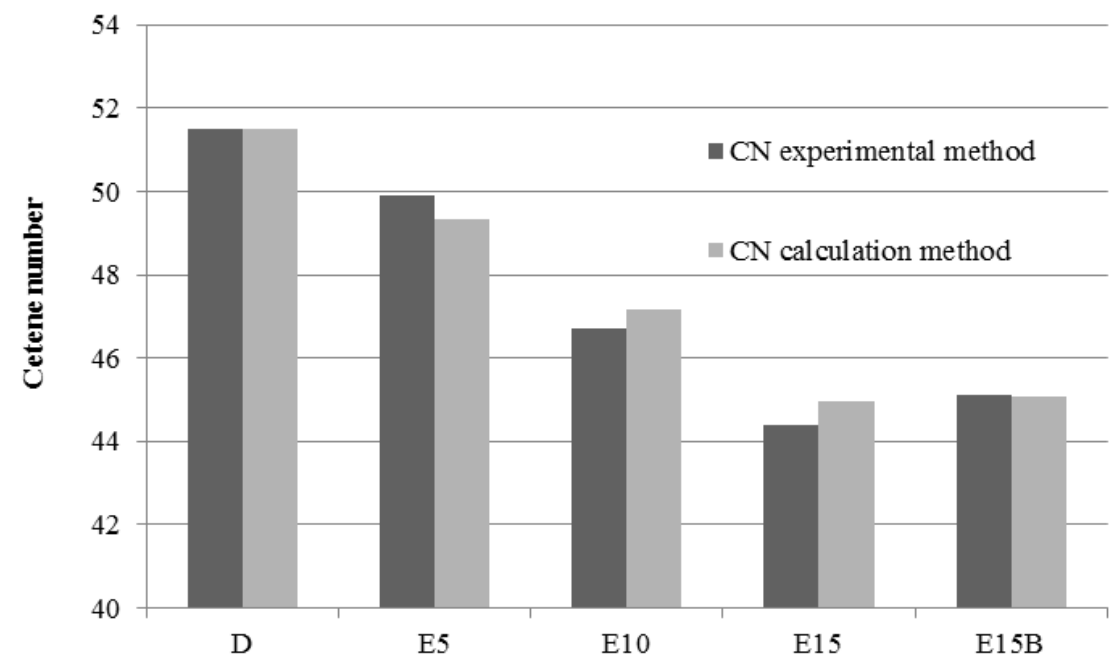

Fig. 4. Cetane number of diesel fuel (D) and its blends with ethanol (E5, E10, E15) and diesel-RME fuels (E15B)

\section{The effect of biofuels on the start of injection with regard to TDC}

The start of fuel injection has a very important influence on the autignition delay, combustion, heat release, engine performance efficiency, power output, economic parameters, exhaust emissions and opacity of the exhaust (Rakopoulos et al., 2007). As graphs in Fig. 5a show, the start of injection of diesel fuel (D) and biofuel blends E5-E15B approaches to TDC with the increased engine load $\left(\mathrm{p}_{\mathrm{e}}\right)$. In addition, the start of injection for biofuel blends E10-E15 containing more anhydrous (99.8 vol\%) ethanol more intensively approaches to TDC. These changes can be to some extent attributed to the internal leakages of biofuel because presence of ethanol in the fuel blend reduces density and viscosity and thus increases penetration of a lighter biofuel through technological clearances. The engine cycle occurs faster that reduces the amount of biofuel lost due to presence of internal leakages within the plunger-barrel units of in-line fuel pump resulting in earlier start of the fuel injection at a higher rotation speed $1800 \mathrm{rpm}$ of the crankshaft (in Fig. 5.b.).

After engine speed increased to the rated $2200 \mathrm{rpm}$ value, the biofuel blends were injected into the cylinder actually at the same advance angle before TDC regardless of changes in engine load. The exception belonged to the maximum amount of anhydrous ethanol containing blend E15 (Fig. 5 c.), which differed as having the lowest both density (Fig. 2) and kinematic viscosity (Fig. 3.). It is important to stress the fact that the addition of a small (5 vol\%) of more viscous RME substantially reduced the internal leakage within the injection pump and ensured about constant start of biofuel injection with regard to TDC. 
Similar changing behaviour in the start of injection of bio-fuel blends with engine load, speed and biofuel properties confirm the results obtained by other authors (Rakopoulos et al., 2008, Torres-Jimenez et al. 2011)
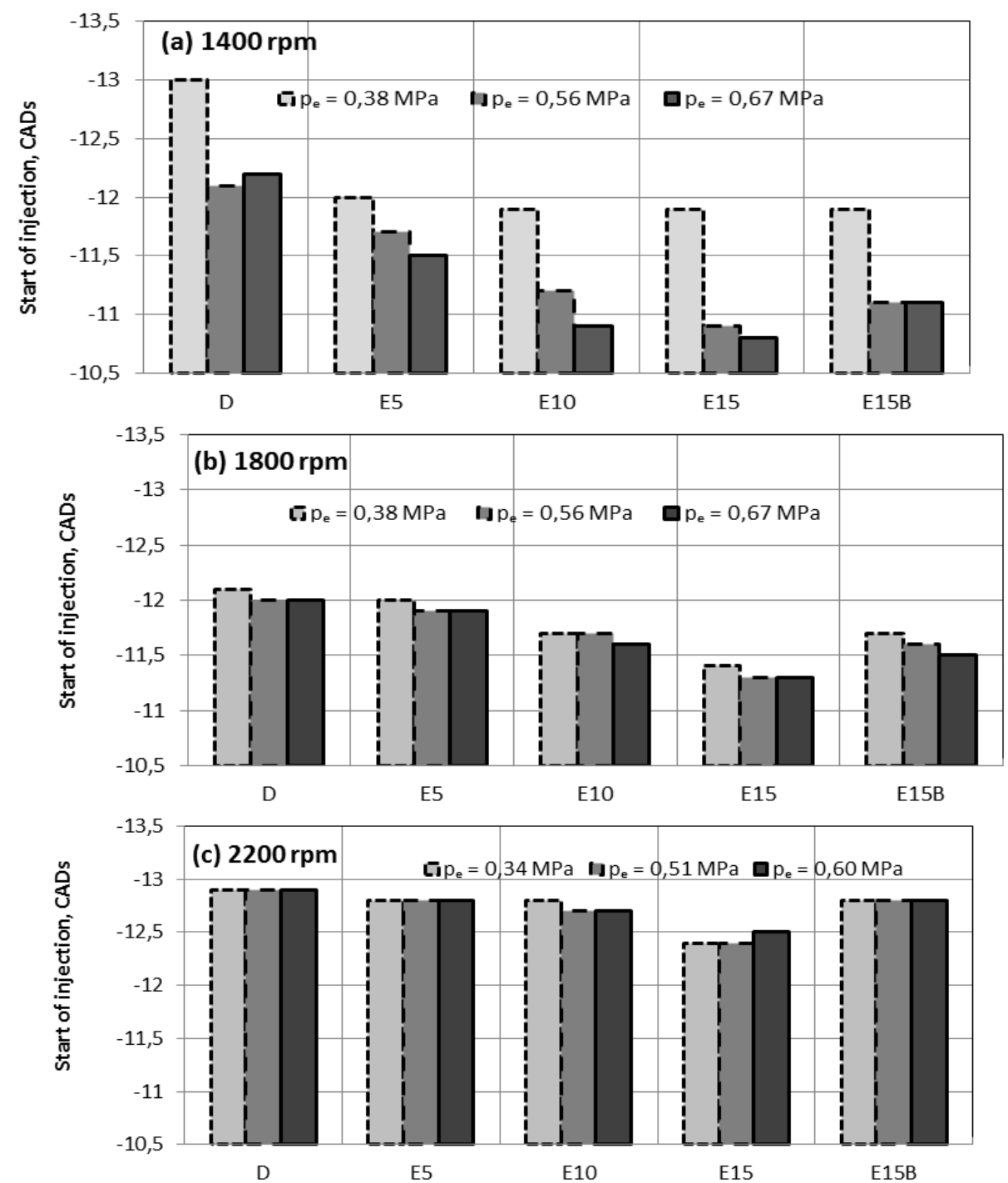

Fig. 5. The start of injection for the engine running on diesel fuel (D) and its blends with ethanol (E5, E10, E15) and ethanol-RME (E15B) at different loads and speeds: a) $1400 \mathrm{rpm}$ b) $1800 \mathrm{rpm} \mathrm{c)} 2200 \mathrm{rpm}$

\section{The biofuels effect on the start of combustion with regard to TDC}

For the case of compression ignition engine, as the start of autoignition normally is accepted the moment when the heat release rate during the chemical 
oxidation reactions exceeds the heat transferred to the environment. By using this methodology, the start of combustion for internal combustion engine determine many scientists (Rakopoulos et al., 2008, Torres-Jimenez et al., 2011).

As graphs in Fig. 6 show, the start of combustion moves (anticlockwise) away from TDC with the increased engine load from $\mathrm{p}_{\mathrm{e}}=0.38$ to $0.67 \mathrm{MPa}$ for all diesel fuel and biofuel blends E5-E15B tested, i.e. the fuel ignites before TDC.
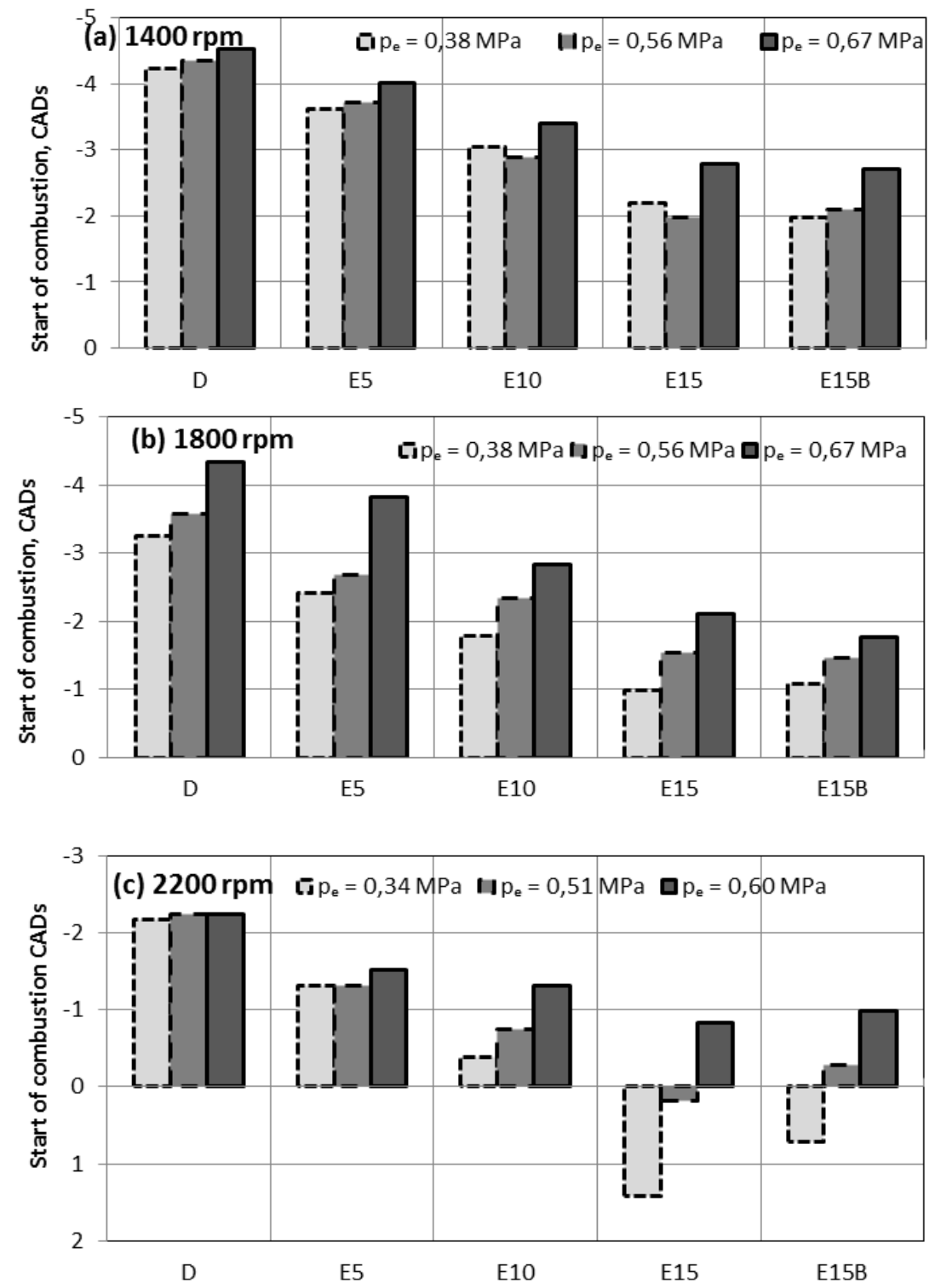

Fig. 6. The start of combustion of the engine running on diesel fuel (D) and its blends with ethanol (E5, E10, E15) and ethanol-RME fuel (E15B) at different loads and speeds of: a) $1400 \mathrm{rpm} \mathrm{b)} 1800 \mathrm{rpm}$ c) $2200 \mathrm{rpm}$ 
This is especially true for the case when the engine operates at the maximum torque mode of $1400 \mathrm{rpm}^{-1}$ and a higher rotation $1800 \mathrm{rpm}^{-1}$ speed. The biofuels autoignite faster for higher engine loads due to a higher temperature of compressed air in the cylinder. At rated $2200 \mathrm{rpm}$ speed, the variation in engine load does not have significant influence on the moment of ignition with regard to TDC because the temperature of gasses in the cylinder is high enough $(\mathrm{T}=1100 \mathrm{~K}$ and beyond) to accelerate the autoignition processes. However, in the case of using a larger quantity of anhydrous ethanol in the blends (E10-E15B) the influence of engine load on the start of autoignition with regard to TDC is more visible because of a large $(827 \mathrm{~kJ} / \mathrm{kg})$ latent heat of vaporisation of the ethanol. Graphs in Fig. 6 show that the start of combustion approaches to TDC for all engine loads and 1400-2200 rpm speeds with the increased percentage of anhydrous ethanol in biofuel blends. At rated engine speed of $2200 \mathrm{rpm}$ and moderate load of $\mathrm{p}_{\mathrm{e}}=0.34 \mathrm{MPa}$, the start of combustion occurred even 0,5 to $1,5^{\circ}$ after TDC when running on biofuel blends E15 and $\mathrm{E} 15 \mathrm{~B}$. The noted changes show that using of a higher amount of anhydrous ethanol in the biofuel blend delays the start of combustion - similar results presented other researchers (Park et al., 2012).

\section{The effect of biofuels on the autoignition delay}

Fig. 7 shows how does the variation of autoignition delay time $\left(\tau_{\mathrm{i}}\right)$ depends on the use of biofuel blends E5-E15B for various engine loads and speeds. The analysis the graphs shows that for biofuel blends E15 and E15B the autoignition delay increased by $4.4 \%$ and $9.5 \%$ compared to normal diesel running $1400 \mathrm{rpm}$ and maximum $\left(\mathrm{p}_{\mathrm{e}}=0.67 \mathrm{MPa}\right)$ load. When the engine load was $\mathrm{p}_{\mathrm{e}}=0.56 \mathrm{MPa}$ (about 75\%), the effect of using anhydrous ethanol was greater, and the difference compiled about $15.1 \%$ and $16.3 \%$, respectively. When running at moderate engine load of $\mathrm{p}_{\mathrm{e}}=0.38 \mathrm{MPa}$, the autoignition delay increased by $10.7 \%$ and $13.2 \%$ compared with diesel fuel case.

After the engine speed was increased to $1800 \mathrm{rpm}$ (Fig. 7b), the changes in the autoignition delay period $\tau_{\mathrm{i}}$ with the percentage of anhydrous ethanol used and thus the cetane number of biofuel remained almost the same as those measured when running an engine at maximum torque $1400 \mathrm{rpm}$ mode. At engine load of $\mathrm{p}_{\mathrm{e}}$ $=0.67 \mathrm{MPa}$, the use of ethanol-diesel fuel blends E5, E10, E15 and E15B the autoignition delay increased by $5.4 \%, 14.3 \%, 20.0 \%$ and $27.2 \%$, respectively, compared with the normal diesel fuel case. The autoignition delay period increased by $9.5 \%, 11.2 \%, 15.9 \%$ and $20.4 \%$, respectively, when running at engine load reduced to $\mathrm{p}_{\mathrm{e}}=0.56 \mathrm{MPa}$. When the engine load was further reduced to $\mathrm{p}_{\mathrm{e}}=0.38 \mathrm{MPa}$, the period $\tau_{\mathrm{i}}$ increased by $8.3 \% 12.1 \% 17.8 \%$ and $20.2 \%$ for the use of respective biofuel blends.

The influence of engine load on the autoigtinion delay was not significant 
when running the engine on normal diesel fuel (D) and diesel fuel blends with a lower percentage of anhydrous ethanol (E5) at rated $2200 \mathrm{rpm}$ speed (Fig. 7 c.).

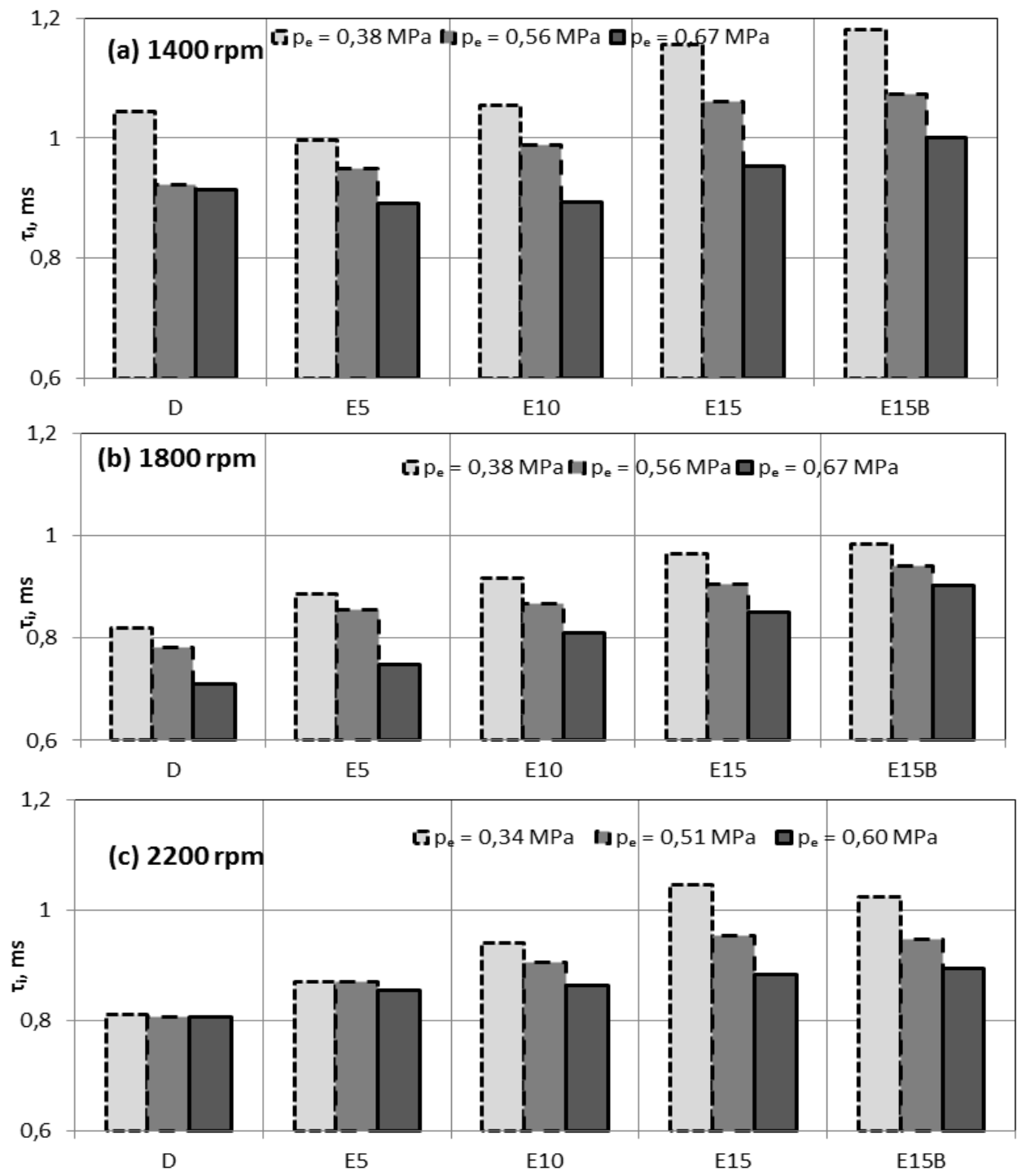

Fig. 7 The autoignition delay period of the engine running on diesel fuel (D) and its blends with ethanol (E5, E10, E15) and ethanol-RME (E15B) at different loads and speeds of : a) $1400 \mathrm{rpm} \mathrm{b)} 1800 \mathrm{rpm}$ c) $2200 \mathrm{rpm}$

The influence of engine load on the autoignition delay period was more substantial only when using the biofuel blends E10-E15B with a higher oxygen concentration $(3.8 \mathrm{vol} \%$ to $6.1 \mathrm{vol} \%)$. The influence of the added bioethanol to diesel fuel on the autoignition delay became much more significant when running at a 
lower load of $\mathrm{p}_{\mathrm{e}}=0.34 \mathrm{MPa}$ and speed of $2200 \mathrm{rpm}$. When running the engine at $\mathrm{p}_{\mathrm{e}}=0.34 \mathrm{MPa}$, i.e. (50\%) load of nominal value, on biofuel blends E5, E10, E15 and $\mathrm{E} 15 \mathrm{~B}$, the autoignition delay $\tau_{\mathrm{i}}$ was $7.1 \%, 15.6 \%, 28.9 \%$, and $26,0 \%$ longer, respectively, compared to the normal diesel fuel case. After engine load was increased to maximum of $\mathrm{p}_{\mathrm{e}}=0.60 \mathrm{MPa}$, the autoignition delay period $\tau_{\mathrm{i}}$ increased by $5.9 \%, 6.9 \%, 9.5 \%$ and $10.8 \%$, respectively. It should be noted that a smart increase in period $\tau_{\mathrm{i}}$ was mainly slowed down due to a higher temperature of the air charge compressed inside the cylinder that contributed to shortening of the autoignition delay for all biofuel blends in this particular case (Heywood, 1988).

The test results obtained in this study match well with the findings of other researchers (Rakopoulos et al., 2008, Torres-Jimenez et al., 2011, Fang et al., 2013; Hulwan. Joshi, 2011) who also investigated the effects of various biofuel blends on the autoignition delay.

\section{Conclusions}

1. The content of fuel bound oxygen was equal to $2.1 \%, 3.8 \%, 5.6 \%$ and $6.1 \%$ (vol\%) for anhydrous ethanol, diesel fuel and RME blends E5, E10, E15, $\mathrm{E} 15 \mathrm{~B}$, respectively, and the content of oxygen included into commercial diesel fuel (0.4\%) met the standard LST EN 590: $2009+$ A1. The carbon-to-hydrogen ratio $(\mathrm{C} / \mathrm{H})$ decreased by $2.2 \%, 4.3 \%, 6.5 \%$ and $6.9 \%$ (by mass) for respective biofuel blends and the content of hydrogen in biofuel blends remained almost unchangeable and compiled about $12.6 \%$.

2. The density of ethanol-diesel fuel blends E5, E10 and E15 decreased by $0.33 \%, 0.65 \%$ and $0.95 \%$ at the temperature of $20{ }^{\circ} \mathrm{C}$, and the kinematic viscosity decreased by $7.8 \%, 11.0 \%$ and $13.0 \%$, respectively, at the temperature of $40{ }^{\circ} \mathrm{C}$ due to the addition of $5 \%, 10 \%, 15 \%$ (by volume) of anhydrous (99.8\%) ethanol to diesel fuel. The addition to ethanol-diesel fuel blend E15 of the 5vol\% of RME for the account of diesel fuel the biofuel density and kinematic viscosity reduced by $0.56 \%$ and $10.8 \%$, respectively, compared with diesel fuel.

3. Adding of $5 \mathrm{vol} \%$ (E5), $10 \mathrm{vol} \%$ (E10), 15vol\% (E15) of anhydrous ethanol to diesel fuel $(\mathrm{CN}=51.5)$, and preparation of a three-component blend E15B the cetane number, which was established by using experimental motor method, reduced to $49.9,46.7,44.4$ and 45.1 . This means that the cetane rating of respective biofuel blends was $4.2 \%, 8.4 \%, 12.7 \%$ and $12.5 \%$, lower than that of the normal diesel fuel.

4. Using of ethanol-diesel E5, E10, E15, and ethanol-diesel-biodiesel E15B blends the autoignition delay time $\tau_{\mathrm{i}}$ increased by $0,058,0,128,0,233$, and $0,211 \mathrm{~ms}$, i.e. by $7.1 \%, 15.6 \%, 28.9 \%$, and $26.0 \%$, respectively, compared to normal diesel running at moderate $\mathrm{p}_{\mathrm{e}}=0.34 \mathrm{MPa}$ (about 50\%) load and rated speed of $2200 \mathrm{rpm}$. With the engine running at intermediate $1800 \mathrm{rpm}$ mode and maximum torque corresponding speed of $1400 \mathrm{rpm}$, the autoignition delay changing tendencies with the increased percentage of ethanol in biofuel blend and engine load remained similar. 


\section{References}

1. Barabás, I.; Todorut, A.; Ldean, D. Performance and emission characteristics of an CI engine fueled with diesel-biodiesel-bioethanol blends. Fuel, 2010, vol. 89, p. 3827-3832.

2. Çetin, M.; Yüksel, F.; Kuş, H. Emission characteristics of a converted diesel engine using ethanol as fuel. Energy for Sustainable Development, 2009, vol. 13, p. 250-254.

3. Hulwan, D.B.; Joshi, S.V. Performance, emission and combustion characteristic of a multicylinder DI diesel engine running on diesel-ethanol-biodiesel blends of high ethanol content. Applied Energy, 2011, vol. 88, p. 5042-5055.

4. European standard. (1994). "Petroleum products-Transparent and opaque liquids-Determination of kinematic viscosity and calculation of dynamic viscosity." EN ISO 3104+AC: 1994.

5. European standard. (1998). "Petroleum products-Determination of the ignition quality of diesel fuels-Cetane engine method.” EN ISO 5165:1998.

6. European standard. (1999a). "Crude petroleum and petroleum productsDetermination of density-Oscillating U-tube method." EN ISO 12185:1999.

7. Heywood, JB. Internal combustion engine fundamentals. McGrow-Hill International Editions. Printed in Singapore; 1988, p. 930.

8. Labeckas, G. Biodegaly naudojimas vidaus degimo varikliuose. Biomasès inžinerija, II tomas. Kaunas, 2008. p. 117-192.

9. Labeckas, G.; Slavinskas, S.; Mažeika, M. The effect of ethanol-dieselbiodiesel blends on combustion, performance and emissions of a direct injection diesel engine. Energy Conversion and Management, 2014, vol. 79, p. 698-720.

10. Lapuerta, M.; García-Contreras, R.; Agudelo, J.R. Lubricity of ethanolbiodiesel-diesel fuel blends. Energy Fuels, 2010, vol. 24, p. 1374-1382.

11. LI, D. et al. Physico-chemical properties of ethanol-diesel blend fuel and its effect on performance and emissions of diesel engines. Renewable Energy, 2005, vol. 30, p. 967-976.

12. Matijošius, J. Dyzelinio variklio ekologiniu rodikliu gerinimas naudojant biobutanolio ir biodyzelino mišinius: daktaro disertacija, VGTU 2011.

13. Pukalskas, S. Etilo spirito įtaka dyzelinio variklio ekonomiškumui ir dūmuotumui: daktaro disertacija. Vilnius: VGTU, 2002.

14. Qiang F. et al. Effects of ethanol diesel biodiesel blends on combustion and emissions in premixed low temperature combustion. Applied Thermal Engineering, 2013, vol. 54, p. 541-548.

15. Rakopoulos, C. D.; Antonopoulos, K. A.; Rakopoulos, D. C. Experimental heat release analysis and emissions of a HSDI diesel engine fueled with ethanol-diesel fuel blends. Energy, 2007, vol. 32, p. 1791-1808.

16. Rakopoulos, D. C. et al. Effects of ethanol-diesel fuel blends on the performance and exhaust emissions of heavy duty DI diesel engine. Energy Conversion and Management, 2008, vol. 49, p. 3155-3162.

17. Shahir, S.A. et al. Feasibility of diesel-biodiesel-ethanol/bioethanol blend as existing CI engine fuel: An assessment of properties, material 
compatibility, safety and combustion. Renewable and Sustainable Energy Reviews, 2014, vol. 32, p. 379-395.

18. Park, S. H. et al. Effect of early injection strategy on spray atomization and emission reduction characteristics in bioethanol blended diesel fueled engine. Energy, 2012, vol. 39, p. 375-387.

19. Torres-Jimenez, E et al. Physical and chemical properties of ethanoldiesel fuel blends. Fuel, 2011, vol. 90, p. 795-802.

20. Weber De Menezes, E. et al. Effect of ethers and ether/ethanol additives on the physicochemical properties of diesel fuel and on engine tests. Fuel, 2006, vol. 85, p. 815-822.

21. Гарипов, М. Д.; Еникеев, Р. Д.; Сакулин, Р. Ю. Рабочие прочессы и конструирование двигателей, работающих на биотопливах: учебное пособие. Уфимский государственный авиационный технический университет. Уфа: УГАТУ, 2008. 107 с. 